\title{
MENINGKATKAN PRESTASI BELAJAR IPA DENGAN MENERAPKAN METODE STUDENT TEAMS ACHIEVEMENT DIVISIONS BERBANTUAN CD PEMBELAJARAN PADA SISWA KELAS IV SEMESTER 1 DI SD N KARANGTOWO
}

\author{
Suratmi \\ Guru SDN Karangtowo Karangtengah Demak \\ Jawa Tengah, Indonesia
}

\begin{tabular}{l} 
Info Artikel \\
\hline Sejarah Artikel: \\
Diterima April 2016 \\
Disetujui September 2016 \\
Dipublikasikan Desember \\
2016 \\
\\
\hline Keywords: \\
STAD, CD Pembelajaran, \\
Prestasi Belajar \\
--_-_
\end{tabular}

\begin{abstract}
Learning science in elementary school are learning that should be understood students to understand the various problems that occurred in the neighborhood. The subjects were fourth grade students of Karangtowo elementary school Karangtengah District of Demak district by the number of students 27 students. Issues to be discussed include how to improve learning achievement and behavioral changes after making science learning material structure and function of plant parts in the fourth grade students of Karangtowo elementary school Karangtengah District of Demak district after learning method STAD with the application learning CD. This study uses classroom action research design with two cycles. Each cycle consists of action planning, action, observation, and reflection. Before taking action done prior learning pre-cycle ago, which is used as the basis for corrective actions implemented.

Results of preliminary tests prior to the act of research, namely in pre-cycle average value obtained at 66.30. Because the value obtained student in materials science learning structure and function of plant parts are still considered very poor, so it needs to be implemented corrective action learning cycle I. In the first cycle the average value obtained for class 78.89. Values are achieved by students in the first cycle have been increased quite dramatically, but the value achieved is still quite a lot that has not reached the minimum standards in the standar value is 73.00. In addition, the participation of students is not yet active. There are still a lot of quite a lot of students are shy in presenting their opinions and ask questions. However, participation of students in the first cycle is much better than before the implementation of the action. Based on the results achieved, it is necessary to repair the holding of the second cycle. In the second cycle of the value achieved by students has increased very significantly by an increase of 86.30. Participant enthusiasm of the students and of students in the second cycle is much better. There have been many students who dared to ask and answer various matters relating to the learning science material structure and function of the plant.
\end{abstract}

\section{Abstrak}

Pembelajaran IPA di SD adalah pembelajaran yang dasar yang harus dipahami siswa untuk memahami berbagai permasalahan yang terjadi di lingkungan sekitar. Subjek penelitian ini adalah siswa kelas IV SD Negeri Karangtowo Kecamatan Karangtengah Kabupaten Demak dengan jumlah siswa 27 siswa. Permasalahan yang dibahas yaitu bagaimana meningkatkan prestasi belajar serta perubahan perilaku setelah melakukan pembelajaran IPA materi struktur dan fungsi bagian tumbuhan pada siswa kelas IV SD Negeri Karangtowo Kecamatan Karangtengah Kabupaten Demak setelah pembelajaran menggunakan metode STAD dengan penerapan CD Pembelaran. Penelitian ini menggunakan desain penelitian tindakan kelas dengan dua siklus. Tiap-tiap tindakan siklus terdiri atas perencanaan, tindakan, observasi, dan refleksi. Sebelum melakukan tindakan dilakukan terlebih dahulu pembelajaran pra siklus, yang digunakan sebagai dasar dilaksanakan tindakan perbaikan.

Hasil tes awal sebelum diadakannya tindakan penelitian, yaitu pada prasiklus nilai rata-rata yang diperoleh sebesar 66,30. Karena nilai yang didapat siswa dalam pembelajaran IPA materi struktur dan fungsi bagian tumbuhan masih dirasa sangat kurang, sehingga perlu dilaksanakan perbaikan pembelajaran siklus I. Pada tindakan siklus I nilai rata-rata kelas diperoleh sebesar 78,89. Nilai yang dicapai siswa pada siklus I sudah mengalami peningkatan yang cukup drastis,namun nilai yang dicapai masih cukup banyak yang belum mencapai standar minimum dalam KKM yaitu 73,00. Disamping itu, partisipasi siswa dalam pembelajaran massih belum aktif. Masih banyak cukup banyak siswa yang malu-malu dalam menyampaikan pendapat maupun bertanya. Tetapi partisipasi siswa dalam pembelajaran siklus I jauh lebih baik dari pada sebelum 
dilaksanakannya tindakan. Berdasarkan hasil yang dicapai, maka perlu diadakannya perbaikan pada siklus II. Pada tindakan siklus II nilai yang dicapai siswa mengalami peningkatan yang sangat signifikan yaitu meningkat sebesar 86,30. Antusiasme siswa dan partisipasi siswa dalam pembelajaran siklus II jauh lebih baik. Sudah banyak siswa yang berani bertanya dan menjawab berbagai hal yang berhubungan dengan pemebelajaran IPA materi struktur dan fungsi bagian tumbuhan.

(c) 2016 Universitas Muria Kudus

\author{
Alamat korespondensi: \\ Program Studi Pendidikan Guru Sekolah Dasar \\ Fakultas Keguruan dan Ilmu Pendidikan Universitas Muria Kudus \\ Kampus UMK Gondangmanis, Bae Kudus Gd. L. It I PO. BOX 53 \\ Kudus \\ Tlp (0291) 438229 ex.147 Fax. (0291) 437198 \\ E-mail: suratmi@gmail.com
}

p-ISSN 2087-9385

e-ISSN 2528-696X 


\section{PENDAHULUAN}

Undang Undang tentang Sistem Pendidikan Nasional No. 20 Tahun 2003 menyatakan bahwa pendidikan nasional bertujuan mencerdaskan kehidupan bangsa, mengembangkan manusia Indonesia seutuhnya, manusia beriman, bertakwa kepada Tuhan Yang Maha Esa, berbudi pekerti luhur, memiliki pengetahuan, ketrampilan, sehat jasmani, rohani, berkepribadian mantap, mandiri, tanggung jawab kemasyarakatan dan kebangsaan. Sistem pendidikan nasional juga harus mampu menjamin pemerataan kesempatan pendidikan, peningkatan mutu serta relevansi dan efisiensi manajemen pendidikan untuk menghadapi tantangan sesuai dengan tuntutan perubahan kehidupan global.

Standar Kompetensi dan Kompetensi Dasar dalam Peraturan Menteri Pendidikan Nasional Nomor 22 Tahun 2006 tentang Standar Isi untuk Satuan Pendidikan Dasar dan Menengah. Standar Kompetensi mata pelajaran Ilmu Pengetahuan Alam (IPA) untuk SD/MI yang berisi bahwa Pendidikan IPA diharapkan dapat menjadi wahana bagi peserta didik untuk mempelajari diri sendiri dan alam sekitar, serta prospek pengembangan lebih lanjut dalam menerapkannya di dalam kehidupan sehari-hari. Tetapi pada kenyataannya prestasi belajar siswa dalam mempelajari konsep-konsep dalam IPA tidak sesuai dengan harapan guru. Hal ini disebabkan oleh beraneka ragam faktor. Sama halnya yang terdapat di SD N Karangtowo Kec. Karangtengah Kab. Demak, masih banyak siswa yang belum memahami konsep-konsep atau materi dalam IPA secara mendalam.

Faktor lain yang menjadi penyebab rendanya kemampuan siswa dalam memahami materi IPA adalah siswa kurang mendapatkan manfaat dari apa yang telah dipelajarainya. Sehingga, siswa hanya beranggapan bahwa apa yang telah dipelajarinya adalah hanya mengikuti kegiatan pembelajaran sebagai rutinitas biasa. Selain itu dalam pembelajaran kurang memanfaatkan media yang tersedia. Hal ini yang membuat anak kurang tertarik dalam mengikuti pembelajaran, apalagi di tambah penggunaan metode yang kurang bervariatif. Salah satu metode yang sering digunakan guru adalah ceramah, metode ini sering sekali digunakan karena dianggap metode yang mudah dan praktis untuk dilakukan serta tanpa persiapan. Sehingga siswa tidak bisa menyerap pelajaran yang diberikan secara maksimal. Akibatnya prestasi belajar siswa dalam pembelajaran IPA masih kurang.

Berdasarkan nilai ulangan mata pelajaran IPA kompetensi dasar struktur dan fungsi bagian tumbuhan, data yang diperoleh menunjukan bahwa hasil belajar siswa kelas IV SD N Karangtowo Kec. Karangtengah Kab. Demak Tahun Pelajaran 2015-2016 masih banyak di bawah KKM (Kriteria Ketuntasan Minimal) yaitu 73, dengan persentase ketidakberhasilan sebesar $74 \%$.

Bertolak dari hasil prestasi belajar siswa yang masih jauh dari harapan peneliti menggunakan alternatif penyelesaian masalah tersebut dengan menerapkan metode STAD (Student Team Achivement Division). Menurut Wina (dalam Dias, 2014) metode STAD adalah metode pembelajaran yang mengelompokan siswa dalam tim kecil, yaitu antara 4-5 orang yang mempuanyai latar belakang akademis, jenis kelamin, ras, atau suku yang berbeda (heterogen). Dengan penggunaan metode ini siswa diajak unutk bekerjasama dan aktif dalam pembelajaran, sehingga diharapkan dengan metode ini prestasi belajar siswa dapat meningkat. Didukung dengan CD Pembelajaran pembelajaran akan lebih menarik perhatian siswa. Menurut Sandiwiradinata (2012:9) Media pembelajaran dalam bentuk $\mathrm{CD}$ pembelajaran berisi gambar-gambar, video, animasi, dan dilengkapi dengan audio untuk memudahkan pemahaman materi terutama materi-materi yang sulit dipahami. Sehingga diharapkan dengan penerapan metode STAD dan didukung menggunakan CD Pembelajaran pembelajaran IPA materi struktur dan fungsi bagian tumbuhan pada siswa kelas IV SD $\mathrm{N}$ Karangtowo Kec. Karangtengah Kab. Demak, prestasi belajar siswa dapat meningkat.

Sesuai dengan identifikasi masalah di atas, maka menjadi fokus penelitian adalah Bagaimana meningkatkan prestasi belajar siswa kelas IV SD Negeri Karangtowo Kec. Karangtengah Kab. Demak materi struktur dan fungsi bagian tumbuhan dengan metode Student Teams Achievement Divisions (STAD) berbantuan CD Pembelajaran? Disamping itu bagaimana perubahan perilaku siswa dalam pembelajaran IPA materi struktur dan fungsi bagian tumbuhan dengan metode Student Teams Achievement Divisions (STAD) berbantuan CD Pembelajaran?

\section{METODE PENELITIAN \\ a. Prosedur Peningkatan Prestasi Belajar}

Desain penelitian ini menggunakan prosedur penelitian tindakan kelas. Penelitian tindakan kelas hanya memusatkan pada permasalahan yang spesifik dan kontekstual. Penelitian tindakan kelas dilaksanakan secara tematik dengan mengikuti prosedur atau 
langkah-langkah tertentu. Penelitian ini menggunakan desain penelitian (PTK) dengan dua siklus, yaitu proses tindakan pada siklus I dan siklus II. Siklus I bertujuan untuk mengetahui kemampuan siswa dalam memahami perkembangbiakan hewan dan tumbuhan. Siklus I digunakan sebagai refleksi untuk melaksanakan siklus II. Hasil proses tindakan pada siklus II bertujuan untuk

Bagan 1. Desain Penelitian Tindakan Kelas

K

$\mathrm{P}$

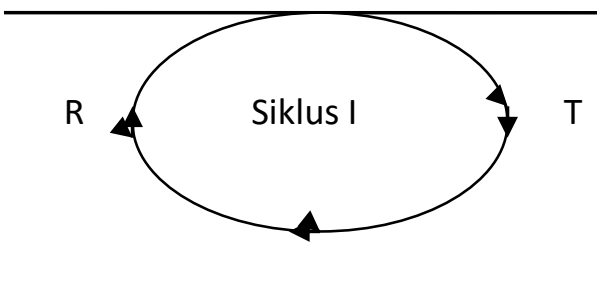

O

\begin{abstract}
Keterangan:
$\mathrm{K}=$ Kondisi Awal

$\mathrm{P}=$ Perencanaan

$\mathrm{T}=$ Tindakan
\end{abstract}

Secara terperinci pelaksanaan penelitian dapat dilihat dari penjabaran per siklus berikut:

\section{Proses Tindakan Siklus I}

Proses tindakan siklus I terdiri atas empat tahap yaitu perencanaan, tindakan, observasi, dan refleksi.

\subsection{Perencanaan}

Refleksi awal berdasarkan observasi atau perenungan terhadap pengalaman mengajar selama ini ditentukan kesalahan. Kesalahankesalahan yang ada dalam pembelajaran IPA harus diminimalkan dengan perencanaan secara umum yaitu kegiatan memilih upaya-upaya yang dapat dilakukan untuk memecahkan masalah pemilihan tersebut, selanjutnya diterangkan dalam perencanaan. Berkaitan dengan penelitian ini, maka perencanaan yang dilakukan adalah:

1. Menyusun satuan pelajaran sesuai dengan penelitian tindakan yang akan dilakukan

2. Menyusun rencana pembelajaran sesuai dengan tindakan yang akan dilakukan

3. Menyusun pedoman pengamatan yaitu meliputi tes, nontes, observasi, dan wawancara

4. Menyusun rencana evaluasi program mengetahui peningkatan keterampilan memahami perkembangbiakan hewan dan tumbuhan setelah melakukan perbaikan dalam kegiatan belajar mengajar yang didasarkan pada refleksi siklus I. Tiap siklus terdiri dari empat tahap, yaitu perencanaan, tindakan, pengamatan, dan refleksi. Untuk memperjelas prosedur pelaksanaan tindakan kelas dapat digambarkan sebagai berikut:

\section{RP}

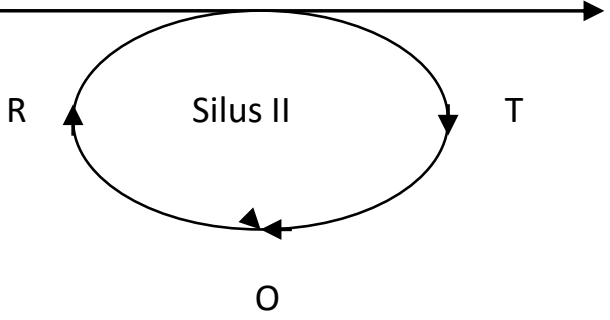

RP Revisi Perencanaan

$=$ Observasi

\subsection{Tindakan}

Pada tahap ini dilakukan tindakan sesuai dengan rencana yang ditetapkan. Tindakan yang dilakukan adalah:

1. Menyampaikan informasi tentang pembelajaran sesuai dengan pedoman perencanaan mengajar.

2. Melaksanakan kegiatan pembelajaran dengan menggunakan medote STAD dan media video, dengan langkah-langkah sebagai berikut.

\section{A. Pendahuluan}

Apersepsi dan Motivasi :

1) Guru mengondisikan kelas

2) Guru menyampaikan tujuan pembelajaran yaitu untuk mengetahui struktur dan fungsi bagian tumbuhan

3) Guru menyanmpaikan indikator pembelajaran

4) Guru bersama siswa membentuk kelompok 3-4 siswa

5) Guru mempersiapan media pembelajaran yang telah disiapkan

B. Kegiatan Inti

* Eksplorasi Dalam kegiatan eksplorasi:

1) Tanya jawab bagian tumbuhan 
2) Memperhatikan pemutaran video tentang struktur dan fungsi bagian tumbuhan

* Elaborasi

Dalam kegiatan elaborasi, guru:

3) Siswa mendengarkan penjelasan dari guru tentang struktur dan fungsi bagian tumbuhan

4) Siswa membentuk kelompok untuk berdiskusi

5) Siswa secara kelompok mengerjakan Lembar Kegiatan Siswa tentang struktur dan fungsi bagian tumbuhan

6) Siswa berdiskusi dalam satu kelompok, siswa yang sudah mengerti, menjelaskan kepada temannya yang belum mengerti sampai mengerti

7) Siswa bersama guru membahas LKS yang telah dikerjakan siswa

8) Guru memberikan kuis yang dijawab secara individu, teman yang lain tidak boleh memberi tahu jawaban kuis yang diberikan

* Konfirmasi

Dalam kegiatan konfirmasi:

9) Guru bersama siswa bertanya jawab meluruskan kesalahan pemahaman, memberikan penguatan dan penyimpulan. Guru memberikan reward untuk siswa yang mendapatkan hasil terbaik

C. Penutup

10) Guru memberikan evaluasi kepada siswa

11) Guru bersama siswa membahas evaluasi

12) Guru bersama siswa menyimpulkan materi yang dibahas hari ini

13) Guru menutup pelajaran dengan salam atau doa

\subsection{Observasi}

Selama penelitian berlangsung, peneliti melakukan pengamatan terhadap kegiatan siswa dalam proses pembelajaran. Melalui lembar observasi, peneliti mengamati tingkah laku siswa selama kegiatan pembelajaran berlangsung. Aspek-aspek yang dinilai adalah (1) sikap positif siswa pada saat memahami struktur dan fungsi bagian tumbuhan, (2) sikap negatif siswa pada saat memahami struktur dan fungsi bagian tumbuhan, (3) respon positif siswa terhadap memahami struktur dan fungsi bagian tumbuhan (4) respon negatif dalam memahami struktur dan fungsi bagian tumbuhan. Caranya dengan memberikan tanda cek (sesuai dengan daftar siswa).

\subsection{Refleksi}

Refleksi dilakukan oleh peneliti setelah selesai melakukan proses tindakan dan pengamatan. Hasil refleksi dijadikan sebagai bahan masukan dalam menetapkan langkah selanjutnya, yaitu pada silus II. Apabila ada kekurangan dalam siklus I, maka hasil tersebut digunakan sebagai bahan perbaikan pada siklus II, apabila ada kamajuan, maka akan dipertahankan, ditingkatkan, dan dikembangkan.

Dengan adanya refleksi, maka kesulitankesulitan dan permasalahan siswa terhadap pelajaran memahami struktur dan fungsi bagian tumbuhan dapat diketahui dan selanjutnya permasalahan tersebut dapat dicarikan jalan keluar.

\section{Proses Tindakan Siklus II}

Proses tindakan siklus II kelanjutan dari siklus I. Langkah-langkah yang dilakukan dalam siklus II sama dengan langkah siklus I. Perbedaannya terletak pada sasaran kegiatan, untuk melanjutkan tahap berikutnya, yaitu memahami struktur dan fungsi bagian tumbuhan dengan menggunakan metode STAD dan media video. Langkah siklus II teridir atas empat tahap yaitu perencanaan, tindakan, observasi, dan refleksi.

\subsection{Perencanaan}

Berdasarkan kelanjutan kegiatan siklus I, kegiatan yang dilakukan pada tahap ini meliputi hal-hal sebagi berikut:

1. Menyusun satuan pelajaran baru sesuai dengan lanjutan materi yang akan diberikan.

2. Menyusun rencana pembelajaran baru sesuai dengan lanjutan tindakan yang akan dilakukan.

3. Menyusun pedoman pengamatan yang meliputi observasi dan wawancara yang merupakan kelanjutan dari siklus I. 


\subsection{Tindakan}

\section{A. Pendahuluan}

Apersepsi dan Motivasi :

1) Guru mengondisikan kelas

2) Guru menyampaikan tujuan pembelajaran yaitu untuk mengetahui struktur dan fungsi bagian tumbuhan

3) Guru menyanmpaikan indikator pembelajaran

4) Guru bersama siswa membentuk kelompok 3-4 siswa

5) Guru mempersiapan media pembelajaran yang telah disiapkan

\section{B. Kegiatan Inti}

* Eksplorasi

Dalam kegiatan eksplorasi:

6) Tanya jawab tentang perkembangbiakan vegetatif buatan

7) Memperhatikan pemutaran video tentang struktur dan fungsi bagian tumbuhan

\section{* Elaborasi}

Dalam kegiatan elaborasi, guru:

8) Siswa mendengarkan penjelasan dari guru tentang struktur dan fungsi bagian tumbuhan

9) Siswa membentuk kelompok untuk berdiskusi

10) Siswa secara kelompok mengerjakan Lembar Kegiatan Siswa tentang struktur dan fungsi bagian tumbuhan

11) Siswa berdiskusi dalam satu kelompok, siswa yang sudah mengerti, menjelaskan kepada temannya yang belum mengerti sampai mengerti

12) Siswa bersama guru membahas LKS yang telah dikerjakan siswa

13) Guru memberikan kuis yang dijawab secara individu, teman yang lain tidak boleh memberi tahu jawaban kuis yang diberikan.

\section{* Konfirmasi}

Dalam kegiatan konfirmasi:

14) Guru bersama siswa bertanya jawab meluruskan kesalahan pemahaman, memberikan penguatan dan penyimpulan

15) Guru memberikan reward untuk siswa yang mendapatkan hasil terbaik

\section{Penutup}

16) Guru memberikan evaluasi kepada siswa

17) Guru bersama siswa membahas evaluasi

18) Guru bersama siswa menyimpulkan materi yang dibahas hari ini

19) Guru menutup pelajaran dengan salam atau doa

\subsection{Observasi}

Selama penelitian berlangsung, peneliti melakukan pengamatan terhadap kegiatan siswa dalam proses pembelajaran. Melalui lembar observasi, peneliti mengamati tingkah laku siswa selama kegiatan pembelajaran berlangsung. Aspek-aspek yang dinilai adalah (1) sikap positif siswa pada saat memahami struktur dan fungsi bagian tumbuhan, (2) sikap negatif siswa pada saat memahami struktur dan fungsi bagian tumbuhan, (3) respon positif siswa terhadap memahami struktur dan fungsi bagian tumbuhan (4) respon negatif dalam memahami struktur dan fungsi bagian tumbuhan. Caranya dengan memberikan tanda cek.

Dengan dilakukannya observasi dalam pembelajaran akan diketahui kekurangan dan kelebihan yang terdapat dalam pembelajaran. Sehingga peneliti dapat mengambil langkah yang tepat dalam pembelajaran yang selanjutnya.

\subsection{Refleksi}

Pada akhir siklus II dilakukan analisis mengenai hasil observasi dan wawancara. Langkah ini ditempuh untuk mengetahui seberapa jauh kemampuan siswa dalam memahami struktur dan fungsi bagian tumbuhan. Kendala apa yang ditemui siswa selama siklus II dalam hal ini peningkatan kemampuan siswa dalam memahami struktur dan fungsi bagian tumbuhan. Bagaimana cara memperbaiki kekurangan-kekurangan berikutnya.

Berdasarkan analisis itu dilakukan refleksi yang meliputi:

1. Pengungkapan hasil pengamatan oleh peneliti tentang kelebihan dan kelemahan kemampuan siswa dalam memahami struktur dan fungsi bagian tumbuhan. 
2. Pengungkapan tindakan-tindakan yang telah dilakukan siswa selama proses pembelajaran.

3. Pengungkapan tindakan-tindakan yang telah dilakukan guru selama mengajar.

\section{b. Instrumen Penelitian}

Instrumen penelitian adalah alat yang digunakan untuk mengumpulkan data yang diteliti, penelitian ini menggunakan dua instrumen, yaitu instrumen tes dan non tes.

\section{Instrumen Tes}

Instrumen tes adalah instrumen yang berupa tes objektif yang berisi perintah pada siswa untuk mengerjakan berbagai petanyaan yang hubungannya dengan pembelajaran IPA terutama materi struktur dan fungsi bagian tumbuhan. Pada instrumen tersebut pedoman penilaian keterampilan bisa langsung dapat dilihat dari hasil mengerjakan latihan dan formatif yang disajian dengan menggunakan metode STAD.

\section{Instrumen Nontes}

Penelitian tindakan kelas ini mengguankan bentuk instrumen nontes yang berupa pedoman observasi atau pengamatan dan pedoman dokumentasi.

\section{a. Lembar Observasi}

Lembar observasi yang digunakan untuk mengamati keadaan, respon, sikap, dan keaktifan siswa selama mengikuti proses pembelajaran berlangsung.

Aspek-aspek yang dinilai adalah (1) sikap positif siswa dalam pembelajaran IPA terutama materi struktur dan fungsi bagian tumbuhan, (2) sikap negatif siswa pada saat pembelajaran IPA terutama materi struktur dan fungsi bagian tumbuhan, (3) respon positif dalam pembelajaran IPA terutama materi struktur dan fungsi bagian tumbuhan dan (4) respon negatif terhadap pembelajaran IPA terutama materi struktur dan fungsi bagian tumbuhan

\section{b. Dokumentasi}

Dokumentasi digunakan sebagai bukti peristiwa dalam pembalajaran. Dalam penelitian ini dokumentasi berupa foto yang digunakan untuk mendokumentasikan kegiatan-kegiatan selama proses pembelajaran berlangsung. Pedoman dokumentasi digunakan untuk mengambil data dokumen siswa ketika proses pembelajaran berlangsung. Aspek-aspek yang didokumentasi meliputi: (1) aktivitas siswa ketika mendengarkan penjelasan dari guru, (2) aktivitas siswa ketika pembelajaran IPA terutama materi struktur dan fungsi bagian tumbuhan menggunakan metode STAD dan menyimak video, (3) aktivitas guru memberikan bimbingan kepada siswa.

\section{Teknik Analisis Data}

Dalam penelitian ini, data yang terkumpul dianalisis secara kualitatif dan kuantitatif.

\section{a. Secara Kuantitatif}

Analisis data hasil tes secara kuantitatif deskriptif dihitung secara persentase dengan langkah-langkah sebagi berikut:

a. Merekap skor yang diperoleh siswa

b. Menghitung skor komulatif dari seluruh aspek

c. Menghitung skor rata-rata

d. Menghitung persentase dengan rumus:

$$
\%=\frac{n}{N} \times 100
$$

\section{Keterangan: \\ $\%=$ Persentase nilai siswa \\ $\mathrm{n}=$ Nilai yang diperoleh \\ $\mathrm{N}=$ Jumlah seluruh nilai}

Hasil perhitungan keterampilan siswa dalam memahami perkembangbiakan hewan dan tumbuhan dengan metode STAD menggunakan CD Pembelajaran dari masingmasing siklus ini dibandingkan. Hasil ini memberikan gambaran mengenai persentase peningkatan keterampilan memahami struktur dan fungsi bagian tumbuhan dengan metode STAD berbantuan CD Pembelajaran.

\section{b. Secara Kualitatif}

Analisis kualitatif dimaksudkan untuk menganalisis data nontes yang diperoleh dari siswa. Secara spesifik analisis data yang dipakai adalah analisis data kualitatif deskriptif. Analisis data kualitatif deskriptif adalah menganalisis data dengan kata-kata atau tulisan tentang tingkah laku manusia yang dapat diamati. Untuk memperoleh data nontes dari siswa yang diteliti akan memberi pertanyaan berupa lembar observasi, dan dokumentasi. Hasil analisis siklus I dan siklus II dibandingkan untuk mengetahui perubahan tingkah laku siswa, dari hasil perbandingan tersebut dapat diketahui peningkatan perubahan tingkah laku siswa. 


\section{HASIL DAN PEMBAHASAN}

Hasil penelitian tindakan kelas pada siswa kelas IV SD N Karangtowo Kec. Karangtengah Kab. Demak adalah sebagai berikut:

\section{a. Kondisi Awal}

Sebagai bahan informasi sebelum melakukan tindakan perbaikan, peneliti melaksanakan penilaian pembelajaran kompetensi dasar memahami struktur dan fungsi bagian tumbuhan untuk mengetahui kondisi awal prestasi belajar siswa. Indikator ketuntasan ditunjukan dengan Kriteria Ketuntasan Minimal (KKM) yaitu 73. Prestasi belajar siswa kelas IV SD N Karangtowo Kec. Karangtengah Kab. Demak, dapat dilihat bahwa nilai terendah 40, nilai tertinggi 100 , dan rata-rata nilai yang diperoleh adalah 66,30 . Persentase siswa yang telah memenuhi KKM atau telah tuntas dalam pembelajaran IPA kompetensi dasar memahami struktur dan fungsi bagian tumbuhan baru $26 \%$. Sedangkan siswa yang belum memenuhi KKM atau belum tuntas mencapai $74 \%$.

\section{b. Siklus I}

Pelaksanaan pembelajaran siklus I bertujuan untuk memperbaiki prestasi belajar siswa kelas IV SD N Karangtowo Kec. Karangtengah Kab. Demak yang masih kurang sesuai dengan harapan. Dalam siklus I ini peneliti memperbaiki prestasi belajar siswa dengan menekankan pada penerapan metode pembelajaran STAD dan CD Pembelajaran. Dengan penerapan perbaikan pembelajaran ini prestasi belajar siswa kelas IV SD N Karangtowo Kec. Karangtengah Kab. Demak kompetensi dasar struktur dan fungsi bagian tumbuhan mengalami peningkatan. Indikator peningkatan prestasi belajar siswa ditentukan dengan Kriteria Ketuntasan Minimal (KKM) yaitu 73 .

Prestasi belajar siswa kelas IV SD N Karangtowo Kec. Karangtengah Kab. Demak yang dicapai dalam pembelajaran memahami struktur dan fungsi bagian tumbuhan menggunakan medote STAD dan penerapan CD Pembelajaran adalah siswa yang mendapatkan nilai 50 sebanyak 1 siswa atau sebesar $4 \%$ dari seluruh jumlah siswa. Siswa yang mendapatkan nilai antara 60 sebanyak 4 siswa atau sebesar $15 \%$. Siswa yang memperoleh nilai 70 sebanyak 5 siswa atau sebesar $19 \%$ dari jumlah siswa. Data tersebut merupakan jumlah siswa yang belum melampaui KKM yaitu sebanyak 10 siswa. Sedangkan jumlah siswa yang sudah melampaui KKM sebanyak 17 siswa yaitu, Siswa yang memperoleh nilai antara 80 sebanyak 8 siswa atau sebesar $30 \%$, sedangkan siswa yang memperoleh nilai dengan rentan nilai 90 sebanyak 5 siswa atau sebesar 19\%, dan 4 siswa atau sebesar $15 \%$ yang mendapatkan nilai 100.

Prestasi belajar siswa kelas IV SD N Karangtowo terdapat nilai terendah 50, nilai tertinggi 100, dan rata-rata nilai yang diperoleh adalah 78,89. Persentase siswa yang telah memenuhi KKM atau telah tuntas dalam pembelajaran IPA kompetensi dasar memahami struktur dan fungsi bagian tumbuhan baru $63 \%$ Sedangkan siswa yang belum memenuhi KKM atau belum tuntas mencapai 37\%. Dilihat dari jumlah nilai rata-rata yang dicapai siswa yaitu 78,89 , nilai tersebut sudah melampaui KKM. Namun dari segi jumlah siswa yang belum sepenuhnya mencukupi nilai KKM sebesar 73 masih cukup banyak. Meskipun masih cukup banyak siswa yang belum memenuhi KKM dari perbaikan siklus I ini prestasi belajar siswa mengalami peningkatan.

Dari segi sikap dalam mengikuti pembelajaran, siswa sudah mulai tertarik dalam pembelajaran. Dalam pembelajaran disajikan video yang menarik perhatian siswa dan disajikan kuis sebagai latihan dalam memahami struktur dan fungsi bagian tumbuhan. Namun, kuis yang diberikan kurang banyak untuk dijadikan latihan, sehingga hal itu nanti yang dijadikan perbaikan dalam pembelajaran siklus berikutnya.

\section{c. Siklus II}

Siklus II dilaksanakan karena hasil yang diperoleh pada siklus I masih belum memenuhi target yang telah ditentukan. Selain itu, masih terdapat tingkah laku siswa yang kurang menunjang pembelajaran. Pelaksanaan tindakan siklus II ini dilaksanakan dengan rencana dan persiapan yang lebih baik dari pada siklus I, tentunya dengan perbaikan-perbaikan yang mengarah pada peningkatan hasil belajar, sehingga hasil penelitian tindakan yang berupa nilai tes evaluasi tentang memahami struktur dan fungsi bagian tumbuhan siswa dapat meningkat. Penelitian siklus II ini juga hendaknya diikuti pula dengan perubahan perilaku siswa menjadi lebih baik. Siswa menjadi lebih aktif dan kreatif serta lebih antusias dalam mengikuti pembelajaran melalui metode STAD dan penerapan CD Pembelajaran.

Prestasi belajar siswa kelas IV SD N Karangtowo Kec. Karangtengah Kab. Demak yang dicapai dalam pembelajaran memahami struktur dan fungsi bagian tumbuhan menggunakan medote STAD dan penerapan CD Pembelajaran pada siklus II adalah siswa yang mendapatkan nilai 60 sebanyak 1 siswa atau 
sebesar 4\%. Siswa yang memperoleh nilai antara 70 sebanyak 1 siswa atau sebesar $4 \%$ dari jumlah siswa. Sehingga jumlah siswa yang belum melampaui KKM sebanyak 2 siswa. Sedangkan jumlah siswa yang sudah melampaui KKM sebanyak 25 siswa yaitu, Siswa yang memperoleh nilai 80 sebanyak 11 siswa atau sebesar $41 \%$. Siswa yang memperoleh nilai 90 sebanyak 8 siswa atau sebesar $30 \%$, sedangkan siswa yang mengadapatkan nilai 100 sebanyak 6 siswa atau sebesar $22 \%$.

Prestasi belajar siswa Kelas IV SD N Karangtowo Kec. Karangtengah Kab. Demak dalam memahami struktur dan fungsi bagian tumbuhan, didapati nilai terendah 60, nilai tertinggi 100, dan rata-rata nilai yang diperoleh adalah 86,30. Persentase siswa yang telah memenuhi KKM atau telah tuntas dalam pembelajaran IPA kompetensi dasar memahami perkembangbiakan tumbuhan dan hewan telah mencapai $93 \%$. Sedangkan siswa yang belum memenuhi KKM hanya $7 \%$.

Hal tersebut sudah membuktikan bahwa dengan pelaksanaan perbaikan pembelajaran siklus II ini, tingkat pemahaman struktur dan fungsi bagian tumbuhanmenggunakan metode STAD dengan menerapkan CD Pembelajaran telah meningkatkan prestasi belajar siswa.

Selain dilihat dari aspek tes, dalam kegiatan pembelajaran siswa sudah mengalami perubahan perilaku dalam mengikuti pembelajaran memahami struktur dan fungsi bagian tumbuhan. Siswa sudah mulai berani bertanya kepada guru apabila mengalami kesulitan, siswa sudah mulai tertarik dengan pembelajaran IPA dengan menggunakan metode STAD menggunakan CD Pembelajaran, keaktifan siswa dalam pembelajaran sudah mulai berkembang dengan baik. Meskipun demikian peran guru dalam meningkat prestasi belajar dan menanamkan rasa percayadiri, senang dengan berbagai pembelajaran harus tetap ditingkatkan.

\section{SIMPULAN}

\section{a. Simpulan}

Penerapan media CD pembelajaran dalam pembelajaran menggunakan metode STAD (Student Teams - Achievement Divisions) dapat meningkatkan prestasi belajar siswa karena dengan metode ini siswa diajak selalu berpikir dan memahami tentang struktur dan fungsi bagian tumbuhan. Disanping itu siswa akan lebih tertarik dan lebih berminat untuk belajar.

Penerapan metode pembelajaran STAD (Student Teams - Achievement Divisions) dan menggunakan CD Pembelajaran dalam pembelajaran IPA materi struktur dan fungsi bagian tumbuhan siswa kelas IV SD N Karangtowo Kec. Karangtengah Kab. Demak dapat meningkatkan prestasi belajar siswa. Hal ini dapat dilihat dari peningkatan nilai rata-rata dari awal yaitu 66,30 mengalami peningkatan pada perbaikan pembelajaran menjadi 78,89 pada siklus I dan 86,30 pada siklus II.

$$
\text { Setelah diadakan perbaikan }
$$
pembelajaran perilaku negatif siswa dalam pembelajaran sudah semakin berubah. Siswa sudah mulai bertanya apabila mengalami kesulitan. Selain itu siswa semakin percaya diri, aktif dalam kegiatan pembelajaran, dan tertarik dengan pembelajaran.

\section{b. Saran}

Penelitian ini dapat digunakan sebagai alternatif pembelajaran pembelajaran IPA materi struktur dan fungsi bagian tumbuhan dan mengatasi masalah-masalah yang dialami siswa. Setelah penelitian dilaksanakan, saran yang dapat diberikan peneliti adalah kreativitas guru sangat dibutuhkan untuk meningkatkan kecerdasan siswa terutama dalam pembelajaran dengan mengenalkan sesuatu yang baru, guru hendaknya memberikan variasi dalam pembelajaran terutama yang berkaitan dengan penggunaan metode yang tepat, bagi siswa disarankan aktif mengikuti pembelajaran yang berkaitan dengan IPA agar mempunyai pengalaman yang luas tentang semua hal yang berkaitan dengan IPA.

\section{DAFTAR PUSTAKA}

Arikunto, Suharsimi. 2013. Prosedur Penelitian Suatu Pendekatan Praktik. Jakarta: PT Rineka Cipta.

Badan Standar Nasional Pendidikan. 2006. Permendiknas RI No. 22 tahun 2006 Tentang Standar Isi untuk Satuan Dikdasmen. Jakarta.

Dalyono, M. 2001. Psikologi Pendidikan. Jakarta: Rineka Cipta.

Daryanto. 2011. Penelitian Tindakan Kelas Dan Penelitian Tindakan Sekolah. Yogyakarta: Gava Media.

Dimyati dan Mudjiono. 2009. Belajar dan Pembelajaran. Jakarta: Rineka Cipta.

Haryanto. 2010. Pengertian Prestasi Belajar. Diunduh 8 November 2014. Pukul 05:10.dari hhttp://belajarpsikologi.com/pengertianprestasi-belajar. 
Sapriati, dkk. 2013. Pembelajaran IPA di SD.

Tangerang Selatan: Universitas Terbuka.

Huda, Miftahul. 2015. Model-model Pengajaran dan Pembelajaran. Isu-isu Metodis dan Paradigmatis. Yogjakarta: Pustaka Pelajar.

Sapriati, dkk. 2013. Pembelajaran IPA di SD. Tangerang Selatan: Universitas Terbuka.

Shoimin, Aris. 2014. 68 Model Pembelajaran Inovatif dalam Kurikulum 2013. Yogjakarta: Ar-Ruzz Media.

Srini, M. Iskandar. 1996. Pendidikan Ilmu Pengetahuan Alam. Jakarta: Kemendikbud.

Suhartanti, Dwi. Isnani Aziz Zulaikha, Yulinda Erma S. 2008. Ilmu Pengetahuan Alam Untuk Kelas VI SD. Jakarta: Pusat Perbukuan Depdiknas.

Sutrisno, Leo. dkk. 2007. Pengembangan Pembelajaran IPA di SD. Jakarta: Dindik Depdiknas.

Taniredja, Tukira. 2014. Model-model Pembelajaran Inovatif dan Efektif. Bandung: Alfabeta.

Tim-FKIP UT. 2014. Pemantapan Kemampuan Profesional. Tangerang Selatan: Universitas Terbuka.

W, Sri Anitah, dkk. 2013. Strategi Pembelajaran di SD. Tangerang Selatan: Universitas Terbuka. 